\title{
Biomass of dwarf pine in the Orlické hory Mountains
}

\author{
D. Dušek, J. Novák, D. Kacálek, M. Slodičák
}

Forestry and Game Management Research Institute, v.v.i., Opočno Research Station, Na Olivě 550, CZ-517 73 Opočno, Czech Republic,e-mail:dusek@vulhmop.cz

\begin{abstract}
Dušek D., Novák J., Kacálek D., Slodičák M. 2012: Biomass of dwarf pine in mountain forest ecosystem. - Beskydy, 5 (2): 181-186

In order to evaluate weight and nutrients content in dwarf pine biomass, sample trees were taken for destructive analysis in the formerly air-polluted Orlické Hory Mountains. Investigated stand of dwarf pine was planted in 1988-1989 within clearcut at elevation 1060-1110m (NW aspect, Sorbeto - Piceetum). Totally 29,000 kg.ha-1 of dry biomass was accumulated in the stand. Above-ground biomass accounts for $27,000 \mathrm{~kg}$ (needles $8,000 \mathrm{~kg}$ and wood $19,000 \mathrm{~kg}$ ) and main root biomass represents ca 2,000 kg.ha-1. The biomass of dwarf pine stand contained following amounts of nutrients per hectare: $153 \mathrm{~kg}$ of Nitrogen (from this 64\% in needles, $27 \%$ in wood and $8 \%$ in roots), $14.5 \mathrm{~kg}$ of Phosphorus (52\% in needles), $46 \mathrm{~kg}$ of Potassium ( $52 \%$ in needles), $22 \mathrm{~kg}$ of Calcium (45\% in needles) and $15 \mathrm{~kg}$ of Magnesium (40\% in needles and $44 \%$ in wood).
\end{abstract}

Keywords: dwarf pine, biomass, nutrients, biological amelioration, the Orlické hory Mts.

\section{Introduction}

Forests in the Czech Republic are under heavy anthropogenic pressure. The main factors are air pollution, pollutant deposition, change of natural forest ecosystems and also global climate changes (Lomský, Šrámek 2004). Dwarf pine (Pinus mugo Turra) is considered a suitable species for sites affected by extreme frost stress and can be used as nurse species first substituting and later fostering commercially important tree species in mountain sites affected by disturbances (Balcar et al. 2011). The changes in environmental conditions caused by acidic air pollution did not allow renewing forest stands within large mountain areas in 1980's. The components of the pollutants deteriorated properties of naturally acidic soil changing them to even more acidic ones. This led to a loss of base nutrients. However, nutrients may be returned to the soil via litter-fall; this is a part of an ameliorative function of forest. Dwarf pine was able at least to restore and keep a soil cover, and thus provided an anti-erosion function of forest.
The ameliorative effect of trees depends especially on chemical properties of their litter-fall and, subsequently, on decomposition processes of necromass. Therefore, scientific knowledge of nutrient contents in biomass of particular forest species is necessary for better understanding their roles in forest ecosystems. The main objective of this paper is to evaluate an amount of aboveground biomass of dwarf pine and to quantify a content of main nutrients in particular biomass components. The question is: Which part of dwarf pine biomass is important as a potential source of nutrients?

\section{Material and methods}

Three plots were established in dwarf pine stands in the Velká Deštná Mt., the Orlické hory Mts., North-Eastern Bohemia in 2002. The stand was established by planting on clear cut in 1988-1989. The plots are situated at an altitude of $1060-1110 \mathrm{~m}$ on north-western slope, the co-ordinates are $50^{\circ} 18^{\prime} 13^{\prime \prime}, 16^{\circ} 23^{\prime} 58^{\prime \prime}$. Area of each plot was $100 \mathrm{~m}^{2}(10 \times 10 \mathrm{~m})$. 
All dwarf pine individuals in the each plot were measured (height, width of crown in north-south and east-west directions) and, subsequently, three samples (one shrub per plot) were selected to evaluate biomass amount. The samples were divided into particular annual shoots and particular components (needles, bark and wood) were weighed separately. Bark and wood of annual shoots older than 5 years were processed altogether. Additionally, the samples for chemical analysis (nutrient contents in needles, bark and wood) were taken from the other individuals. Merely weight and nutrients content of coarse roots were evaluated, because of impossibility to obtain all (particularly fine) roots.

The samples were dried first in the open air and afterwards in a laboratory at $105^{\circ} \mathrm{C}$ and weighed. Total nitrogen (N) concentration was analyzed according to Kjeldahl procedure and phosphorus $(\mathrm{P})$ concentration was determined colorimetrically. An atomic absorption spectrophotometer was used to determine total potassium $(\mathrm{K})$ concentration by flame emission, and calcium (Ca) and magnesium ( $\mathrm{Mg}$ ) by atomic absorption after addition of La. Weight of dry biomass and nutrient content were recalculated into a hectare area.

\section{Results}

The amounts and concentrations of nutrients were different in the particular biomass components. Nitrogen concentrations ranged between 1.1-1.3\% in needles, $0.6-1.2 \%$ in bark and $0.2-0.7 \%$ in wood. Phosphorus concentrations were $0.07-0.11 \%$ (needles), $0.07-0.15 \%$ (bark), $0.02-0.09 \%$ (wood). Potassium concentrations were $0.20-0.36 \%$ (needles), $0.31-0.44 \%$ (bark), $0.07-0.28 \%$ (wood). Calcium concentrations were $0.09-0.32 \%$ (needles), $0.10-0.21 \%$ (bark), $0.04-0.06 \%$ (wood). Magnesium concentrations were $0.06-0.09 \%$ (needles), $0.10-0.11 \%$ (bark), $0.03-0.08 \%$ (wood). The lowest concentrations of all nutrients were found in wood. Generally, the nutrient concentration was lower in older annual shoots in all components (needles, bark and wood). Only calcium concentrations in needles and bark were higher in older annual shoots (fig. 1).

Nutrients concentrations in coarse roots were similar to concentrations in aboveground biomass, excepting calcium concentration, which was approximately three times higher.

The weight of dry mass of average shrub was approximately $8.4 \mathrm{~kg}$. Wood accumulated ca. $64 \%$ of biomass, but needles were higher in nutrients, except for magnesium (tab. 1). Coarse roots biomass comprised only $7 \%$ of total biomass, but it does not represent biomass
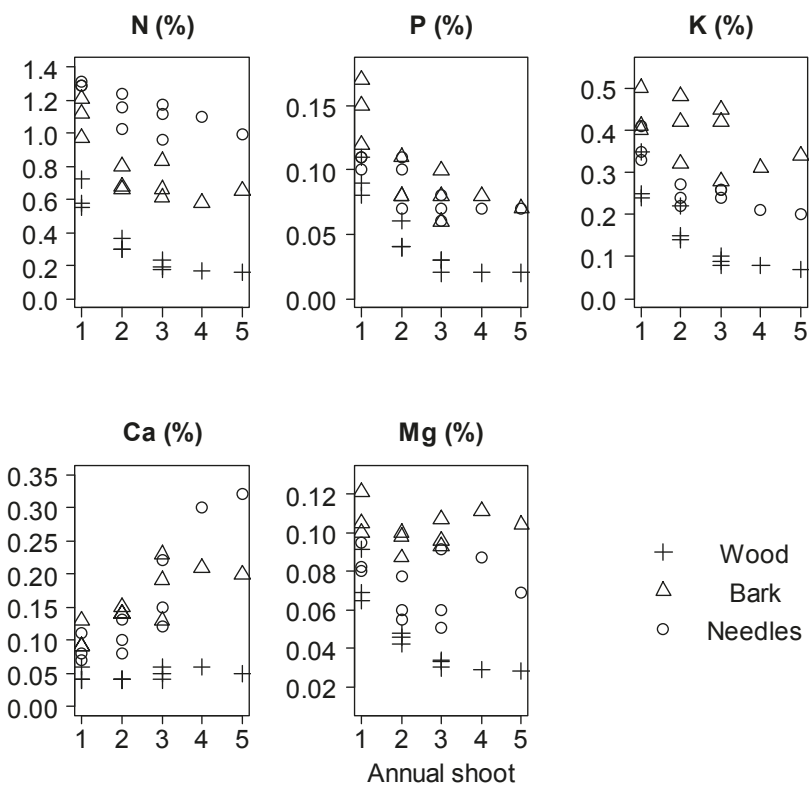

Fig. 1: The concentrations of nutrients in particular annual shoots. 
of all roots. Weight of dry mass per hectare was approximately $29,000 \mathrm{~kg}$ (considering density 3,500 shrubs.ha-1 ${ }^{-1}$.

Such a dwarf pine stand contains ca $153 \mathrm{~kg}$ of nitrogen $(64 \%$ needles, $27 \%$ wood and $8 \%$ roots respectively), $14.5 \mathrm{~kg}$ of phosphorus ( $52 \%$ needles), $46 \mathrm{~kg}$ of potassium ( $52 \%$ needles), $22 \mathrm{~kg}$ of calcium ( $45 \%$ needles) and $15 \mathrm{~kg}$ of magnesium (40\% needles, $44 \%$ wood).

\section{Discussion}

Brewer et al. (1994) evaluated nutrient contents in needles of six annual shoots of dwarf pine at different elevations $(490-1350 \mathrm{~m}$ a. s. l.) in Bohemian peatbogs. The needles were $0.92-1.15 \%$ nitrogen, $0.10-0.12 \%$ phosphorus, $0.39-0.61 \%$ potassium, $0.15-0.38 \%$ calcium, and $0.05-0.11 \%$ magnesium. Calcium content clearly increased with age of needles, whereas trend in nitrogen, potassium and magnesium was inversed. This is quite consistent with our findings. Brewer et al. (1994) found no substantial differences at various elevations. A general trend toward increasing calcium and decreasing nitrogen, potassium and magnesium with needle's age was also found by Bylińska et al. (2000) and Špinlerová, Martinková (2009).

Špinlerová (2011) investigated above-ground biomass in four transects (within $4 \mathrm{~m}^{2}$ area per transect, thus the term transect is questionable), the Hrubý Jeseník Mts. In this study, dry mass totaled 67,000-174,000 kg.ha-1 in 20-150-yearold stands which exceeds substantially our 23-24-year-old study stand. There are three possible causes of this (with presumably decreasing magnitude of influence): 1) Our stand showed substantially sparse density; 2) Our sample strategy leads to negatively biased results; 3 ) Our laboratory preprocessing of biological materials (air drying) caused significant losses due to respiration.

Špinlerová, Martinková (2006) found dwarf pine providing germinating herbs, woody saplings and new plantations with a sufficient shelter in the Orlické hory Mts. Bartoš et al. (2009) found that under conditions of summit parts of the Krkonoše Mts., dwarf pine site showed higher both amount of snow and snow cover among all the woody species tested. However, the dwarf pine stand was not able to retain as much water as 20-year-old spruce stand did during spring thawing.

Tab. 1: Dry weight of biomass and nutrient contents.

\begin{tabular}{|c|c|c|c|c|c|c|c|c|c|c|}
\hline \multirow{2}{*}{\multicolumn{2}{|c|}{ Annual shoots }} & \multicolumn{3}{|c|}{ Biomass (g) } & \multirow[b]{2}{*}{ Mean (g) } & \multirow{2}{*}{$\begin{array}{l}\mathbf{N} \\
(\mathrm{g})\end{array}$} & \multirow{2}{*}{$\begin{array}{c}\mathbf{P} \\
(\mathrm{g})\end{array}$} & \multirow{2}{*}{$\underset{(\mathrm{g})}{\mathbf{K}}$} & \multirow{2}{*}{$\begin{array}{l}\mathrm{Ca} \\
(\mathrm{g})\end{array}$} & \multirow{2}{*}{$\begin{array}{l}\mathrm{Mg} \\
(\mathrm{g})\end{array}$} \\
\hline & & $\begin{array}{l}\text { Sample } \\
\text { shrub } 1\end{array}$ & $\begin{array}{l}\text { Sample } \\
\text { shrub } 2\end{array}$ & $\begin{array}{l}\text { Sample } \\
\text { shrub } 3\end{array}$ & & & & & & \\
\hline \multirow{3}{*}{1} & Needles & 578 & 966 & 779 & 774 & 10.0 & 0.9 & 2.8 & 0.7 & 0.7 \\
\hline & Wood $^{1)}$ & 162 & 237 & 267 & 222 & 1.4 & 0.2 & 0.6 & 0.1 & 0.2 \\
\hline & Total & 740 & 1203 & 1045 & 996 & - & - & - & - & - \\
\hline \multirow{3}{*}{2} & Needles & 610 & 823 & 1019 & 817 & 9.4 & 0.8 & 2.0 & 0.8 & 0.5 \\
\hline & Wood $^{1)}$ & 240 & 477 & 420 & 379 & 1.2 & 0.2 & 0.6 & 0.2 & 0.2 \\
\hline & Total & 850 & 1300 & 1439 & 1196 & - & - & - & - & - \\
\hline \multirow{3}{*}{3} & Needles & 466 & 550 & 534 & 517 & 5.6 & 0.4 & 1.3 & 0.8 & 0.3 \\
\hline & Wood $^{1)}$ & 305 & 354 & 409 & 356 & 0.7 & 0.1 & 0.3 & 0.2 & 0.1 \\
\hline & Total & 771 & 904 & 943 & 873 & - & - & - & - & - \\
\hline \multirow{3}{*}{$4+5$} & Needles & 340 & 278 & 336 & 318 & 3.4 & 0.2 & 0.8 & 0.5 & 0.2 \\
\hline & Wood $^{1)}$ & 4857 & 3964 & 4370 & 4397 & 8.8 & 1.2 & 4.0 & 2.2 & 1.4 \\
\hline & Total & 5197 & 4242 & 4706 & 4715 & - & - & - & - & - \\
\hline \multicolumn{2}{|c|}{ Roots } & 474 & 583 & 763 & 606 & 3.7 & 0.3 & 0.8 & 0.9 & 0.7 \\
\hline \multicolumn{3}{|c|}{ Total (g) } & & & 8386 & 44.3 & 4.2 & 13.2 & 6.4 & 4.3 \\
\hline \multicolumn{3}{|c|}{ Total needles (g) } & & & 2426 & 28.4 & 2.2 & 6.9 & 2.9 & 1.7 \\
\hline \multicolumn{3}{|c|}{ Total wood ${ }^{2)}(\mathrm{g})$} & & & 5354 & 12.1 & 1.7 & 5.5 & 2.6 & 1.9 \\
\hline \multicolumn{3}{|c|}{ Total roots ${ }^{3)}(\mathrm{g})$} & & & 606 & 3.7 & 0.3 & 0.8 & 0.9 & 0.7 \\
\hline \multicolumn{3}{|c|}{ Total biomass (kg.ha $\left.{ }^{-1}\right)$} & & & 29072 & 153 & 15 & 46 & 22 & 15 \\
\hline
\end{tabular}

1) wood and bark together; 2) wood and bark for 1-5 and older annual shoots together; 3) only coarse roots 
The opinions on the dwarf pine function differ when this species is grown in areas where the pine is not considered a native species. Hošek et al. (2007) and Treml et al. (2007), proposed to remove large dwarf pine stands in the Hrubý Jeseník Mts. On the other hand, Maděra et al. (2011) pointed out potential risks resulting from rapid and extensive deforestation in the area of interest. Results of our study support this conclusion as we found that the dwarf pine stands can accumulate the important nutrient's amounts and store them in the mountain ecosystem.

\section{Conclusion}

From our study it can be concluded:

- The accumulated dry mass of biomass of dwarf pine totaled 29,000 kg.ha-l; aboveground biomass weighed $27,000 \mathrm{~kg}(8,000 \mathrm{~kg}$ of needles and $19,000 \mathrm{~kg}$ of wood) and coarse roots weighed $2,000 \mathrm{~kg}$.

- As for nutrient cycling, biomass of needles and to some extent biomass of bark seems to have a crucial role. Younger needles contain more nutrients compared to older ones, excepting calcium.

\section{Literature}

Balcar, V., Špulák, O., Kacálek, D., Kuneš, I. 2011: Obnova lesa ve vyšších horských polohách postihovaných extrémními mrazovými stresy. [Mountain forest renewal on sites affected by extreme frost stress.] Lesnický prüvodce - certifikovaná metodika. VÚLHM, Praha-Strnady, 36 s.

BARTOŠ, J., ŠPUlÁK, O., ČERNOHOUS, V. 2009: Ukládání sněhu ve vztahu k dřevinám vysázeným na kalamitní holině v hřebenové partii horských poloh. [Distribution of snow cover in relation to tree species planted in clearing due to salvage cutting in summit mountain location.] Zprávy lesnického výzkumu, 54 (3): 166-173.

Brewer, J., W., Skuhravý, V., Hrubík, P. 1994: Levels of Major Foliar Chemicals in Needles of Pinus mugo in Bohemian Peatbogs. Ekológia, 13 (3): 235-246.

Bylińska, E., Matusiewicz, O., Winter, B. 2000: Status troficzny kosodrzewiny (Pinus mugo Turra) w Karkonoszach wschodnich. [Trophic status of mountain pine (Pinus mugo Turra) in the Eastern Giant Mountains.] Opera Concortica, 37: 168-174

\section{Acknowledgements}

This study was supported by the long-term project of the Czech Ministry of Agriculture MZE-0002070203. The authors thank two anonymous referees for their helpful comments.

HošEK et AL. 2007: VaV SM/6/70/05. Vliv výsadeb borovice kleče (Pinus mиgo) na biotopovou a druhovou diverzitu arkto-alpinské tundry ve Východních Sudetech (CHKO Jeseníky, NPR Králický Sněžník). [Influence of mountain pine plantations (Pinus mugo) on biotope and species diversity of arctic-alpine tundra in the Eastern Sudetes (Protected landscape area of the Jeseníky Mts., Králický Sněžník National natural preserve).] Návrh managementu téchto porostu. Zpráva o řešení projektu za rok 2007, Hoŕovice, $220 \mathrm{~s}$.

LomsKÝ, B., ŠrÁmeK, V. 2004: Different types of damage in mountain forest stands of the Czech Republic. Journal of Forest Science, 50 (11): 533-537.

Maděra, P., Buček, A., Culek, M., Friedl, M., Kirchner, K., Pecháček, J., Roštínský, P., Sedláček, A., Šenfeldr, M., Š́tinlerová, Z., ŠTykar, J., Tippner, A., VAVŘ́IČ́E, D. 2011: Geobiocenózy horní hranice lesa a vliv porostů borovice kleče na horskou krajinu v Hrubém Jeseníku a rizika spojená s jejich odstraněním. [Geobicenosis of tree line and influence of mountain pine on mountain landscape in the Hrubý Jeseník Mts. and 
risks related to pine removal.] Závěrečná zpráva výzkumného projektu Grantové služby LČR.

ŠPinlerová, Z., Martinková, M. 2006: Growth of mountain pine (Pinus mugo Turra) in relation to the use of other tree species. Journal of Forest Science, 52 (5): 217-225.

Špinlerová, Z., Martinková, M. 2009: Zhodnocení a výběr metod studia agregátu $P i$ nus mugo a příspěvek $\mathrm{k}$ objasnění jeho role v imisních horských oblastech. [Evaluation and choice of methods to study Pinus mugo and contribution to its role in air-polluted mountain areas.] Folia Forestalia Bohemica 7, $88 \mathrm{~s}$.

ŠPinlerovÁ, Z. 2011: Biomasa porostů kleče. [Biomass of mountain pine stands.] In: MADĚRA ET AL.: Geobiocenózy horní hranice lesa a vliv porostů borovice kleče na horskou krajinu v Hrubém Jeseníku a rizika spojená $s$ jejich odstranèním. Závèrečná zpráva výzkumného projektu Grantovéslužby LČR, 167-176.

Treml, V., Banaš, M., Kuras, T., Zeidler, M., Kočvara, R. 2007: Návrh managementových opatření porostů borovice kleče (Pinus mugo) v Hrubém Jeseníku a Králickém Sněžníku. [Proposal of management measures in mountain pine (Pinus mugo) stands, the Hrubý Jeseník Mts. and the Králický Sněžník Mts.] In: HošEK ET AL. VaV SM/6/70/05. Vliv výsadeb borovice kleče (Pinus mugo) na biotopovou a druhovou diverziru arktoalpinské tundry ve Východnich Sudetech (CHKO Jeseníky, NPR Krâlický Snëžník). Návrh managementu téchto porostü. Zpráva o řešení projektu za rok 2007, Hoŕovice, $220 \mathrm{~s}$. 